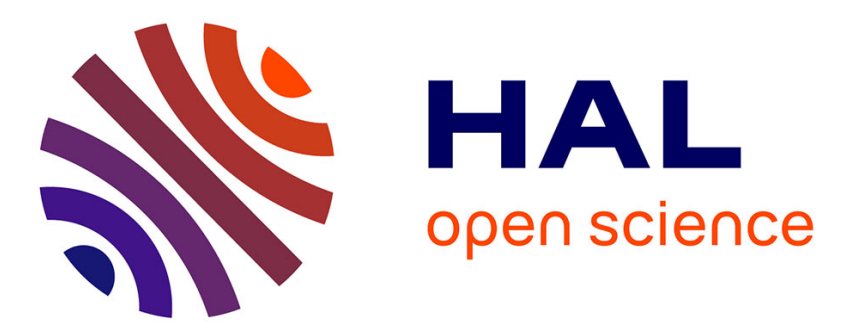

\title{
Simulation Model for a Semi-automated Retail Order Picking System under Uncertainty
}

Sawssen Souiden, Audrey Cerqueus, Xavier Delorme, Jean-Lucien Rascle

\section{To cite this version:}

Sawssen Souiden, Audrey Cerqueus, Xavier Delorme, Jean-Lucien Rascle. Simulation Model for a Semi-automated Retail Order Picking System under Uncertainty. 22nd Working Conference on Virtual Enterprises (PRO-VE 2021), Nov 2021, Saint-Etienne, France. pp.759-767, 10.1007/978-3-030-859695_72. emse- 03350310

\section{HAL Id: emse-03350310 https://hal-emse.ccsd.cnrs.fr/emse-03350310}

Submitted on 25 Nov 2021

HAL is a multi-disciplinary open access archive for the deposit and dissemination of scientific research documents, whether they are published or not. The documents may come from teaching and research institutions in France or abroad, or from public or private research centers.
L'archive ouverte pluridisciplinaire HAL, est destinée au dépôt et à la diffusion de documents scientifiques de niveau recherche, publiés ou non, émanant des établissements d'enseignement et de recherche français ou étrangers, des laboratoires publics ou privés. 
Souiden S., Cerqueus A., Delorme X., Rascle JL. (2021) Simulation Model for a Semiautomated Retail Order Picking System Under Uncertainty. In: Camarinha-Matos L.M., Boucher X., Afsarmanesh H. (eds) Smart and Sustainable Collaborative Networks 4.0. PRO-VE 2021. IFIP Advances in Information and Communication Technology, vol 629. Springer, Cham. https://doi.org/10.1007/978-3-030-85969-5_72

\title{
Simulation Model for a Semi-automated Retail Order Picking System under Uncertainty
}

\author{
Sawssen Souiden ${ }^{1,2}$, Audrey Cerqueus ${ }^{1}$, Xavier Delorme ${ }^{1}$, Jean-Lucien Rascle ${ }^{2}$ \\ ${ }^{1}$ Mines Saint-Etienne, Univ Clermont Auvergne, CNRS, UMR 6158 LIMOS, Institut Henri \\ Fayol, F - 42023 Saint-Etienne France. \\ ${ }^{2}$ Boa Concept SAS, 42000 Saint-Etienne, France. \\ \{audrey.cerqueus,delorme \}@emse.fr; \{ sawssen.souiden, jean- \\ lucien.rascle\}@boaconcept.com
}

\begin{abstract}
Due to the growth of e-commerce, retail order picking problems are nowadays one of the most challengeable issues in logistics networks. Conventionally, semi-automated picking systems are implemented, using a conveyor for transportation and operators for preparation. Customer demand being volatile, the sustainability of the system relies on digitalization and reconfigurability, regarding both the physical and information system. From an operational standpoint, the performance is driven by scheduling approaches to manage the bins' flow however the system is prone to uncertainty. We develop a decision tool based on a simulation model to accurately reflect the real-life situation and the human-conveyor interaction. Our aim is to evaluate the practical flow of the system with uncertain preparation times compared to a theoretical schedule obtained by a deterministic optimization approach. Numerical experiments including an industrial case study are presented and discussed.
\end{abstract}

Keywords: Semi-automated retail order picking system, Scheduling, Optimization, Simulation, Uncertainty.

\section{Introduction}

Order picking (OP) process is one of the most critical components of supply chain management [1]. It plays a fundamental role in ensuring customer fulfillment and in the smooth running of the logistics warehouses networks. There are several OP methods that could be applied depending on the company requirements. Manual picking methods such as "Picker-to-Part" (also called "Pick-by Order") are commonly used in traditional warehousing systems, when the volume of orders is low and the parts are heavy. In these systems, the order picker travels to storage locations in order to bring together the customer's required products. Despite their simplicity, the travel of pickers is an important unproductive part of the OP process. The "Part-to-Picker" method employs the same physical location as the previous method with the integration of material handling system to bring automatically the products to stationary pickers. Such settings are appropriate for high numbers of orders per days 
and for small and heavy products, as the material handling systems are expensive investment, and have less margin of error. "Zone picking" is a semi-automated process which involves a collaboration between a conveyor system for transportation and order picker for orders preparation. This method is typically used for retail order picking (ROP) where the ordered products are small and the delivery dates are tight, as it is the case in e-commerce. As represented in Fig. 1, the OP process consists in retrieving sequentially different items from one zone into another until the constitution of the whole customer order. This ROP method is efficient since it reflects the therein occurring human-machine interactions and allows pickers to focus only on the picking process. However, it could have some organizational issues such as flow gridlocks, which induce costs and delays. Hence, from an operational perspective, the zoning system's performance relies substantially on scheduling approaches of managing the flow within the conveyor system. As all semi-automated OP systems, it is prone to uncertainty due to the variability of the order pickers preparation times and to the conveyor system's state (failure or obstruction of a cell causing the conveyor to stop fractionally or entirely).

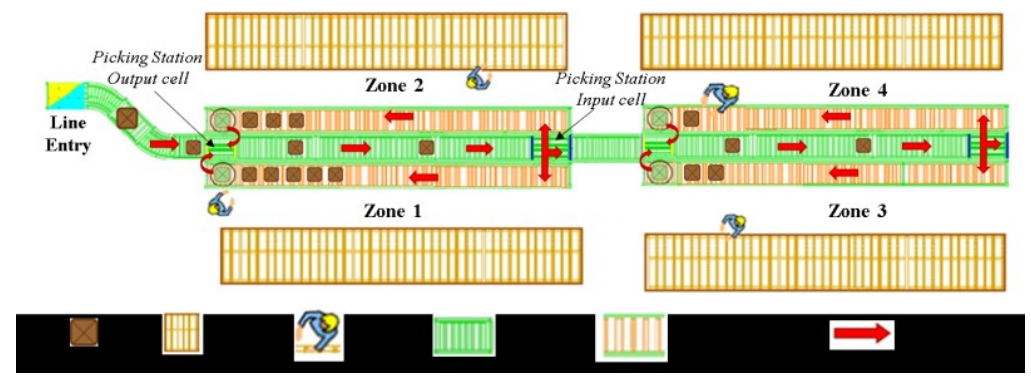

Fig. 1. A schematic diagram of a ROP system under zoning configuration

Nowadays, the customer's demand tends to be fickle and unpredictable and we attend to the booming of e-commerce, intensified by the current health situation which has heightened the need for e-commerce as a vital alternative sales solution [2]. Thus, to remain competitive, companies have to implement digitized and reconfigurable supply chains, on both the physical and information system levels. In this context, we need digital decision-making tools that enable real-time retrieval of the system data and interaction with it on an operational scale. Simulation tools and digital twins can be used as such decision tools enabling the ROP system to communicate and share data for optimal workflows. They also take into account uncertain data and business rules and help to evaluate the system's performance and to highlight bottlenecks. In Industry 4.0, certain tendencies begin to emerge, which lead the logistics companies to adopt a servitization approach by offering customized digital tools developed as a service to their customers. This is in order to strengthen the collaboration with their customers.

In this paper, we develop a simulation model for a ROP system under zone picking configuration. The aim is to rely on a digital simulation tool to evaluate the system's practical flow subject to preparation times uncertainty compared to a deterministic schedule that could be obtained through an exact or approximate optimization. The proposed simulation tool enables to exploit data arising from a servitization process. The reminder of the paper is as follows: In the next section, a literature review of 
related works is presented. Section 3 is dedicated to the ROP simulation model. An industrial study case is discussed in Section 4. Finally, some concluding remarks and research perspectives are given in Section 5.

\section{Literature Review}

The ROP system we study combines the scheduling aspect along with the consideration of uncertainty. The problem of scheduling for OP systems has been widely studied in the literature under a deterministic manner regarding an exact mathematical modeling. For instance, [3] which minimizes the order picker unproductive times while taking into consideration limited buffer capacity and the possibility of skipping some zones and [4] which minimizes the sum of delivery cost and the makespan for multiple zones and limited vehicle capacity. Likewise, many researchers dealt with the scheduling problem in supply chain system by assuming that the input data are known. However, in real-life, scheduling systems are subject to uncertainty caused by the variability of data due to external constraints or factors inherent to the system [5]. It is therefore crucial to model these uncertainties during the scheduling in order to enhance the schedule quality.

The issue of scheduling under uncertainty has received great attention from the researchers in the past decades and it was handled with different methodologies including stochastic, probabilistic, fuzzy programming and robust optimization methods $[6,7]$. Simulation has been successfully adopted in several studies related to scheduling systems, to evaluate the robustness of a schedule and analyze the impact of various uncertain factors [8]. In [9, 10], the authors presented a real-time scheduling methodology based on simulation to optimize job dispatching rules in two different manufacturing systems. They considered different strategies based on various dispatching rules and by comparing those strategies, the efficient one is determined. [11] presents a study for a discrete event simulation with an integrated optimization procedure for a flow-shop layout. A coupling simulation optimization is proposed.

Simulation modeling has also been extensively developed in numerous studies related to logistics and manufacturing systems. However, to the best of our knowledge, simulation approaches for OP systems remain modestly explored in the literature specifically in the context of scheduling.[12] develops queuing simulation models to evaluate the performance of a warehouse that uses sequential zone picking. The proposed queuing network model focuses on several performance measures such as system throughput, order pickers occupancy rate, and the average number of bins in the system based on factors such as the speed and length of the conveyor, the number of picking stations, and the number of picks per station. [13] analyzes the OP system efficiency under congestion situations. The authors drew attention to picker blocking phenomenon and its impact on OP efficiency. The OP system's performance is investigated by implementing a simulation model, which proves that the system efficiency is directly correlated with the number of pickers. The recent work presented in [14] intends to evaluate the performance of bucket brigade OP system in 
which a simulation study is conducted to analyze the effects of various OP configurations.

There are no works that take into account the uncertainty in the ROP scheduling problem. This paper presents a simulation model for a ROP system modeling the flow with a main focus on the variability of preparation times since in human-machine systems, the human is often the main source of uncertainty.

\section{Modeling and Simulating the Retail Order Picking System}

The aim of this paper is to develop a discrete-event simulation model to evaluate a schedule quality applied in the ROP system under uncertainty. The model was built within Arena simulation software Rockwell Automation to reflect real-life situations and the human-conveyor interaction. This section describes the ROP system components and the fundamental business rules integrated in the simulation model.

We consider that the system does not contain loops, that the zones are visited by the bins in the order of their indices. We suppose that the customer order is known and that the products are partitioned on the zones. Thus, the bins visiting sequences are known in advance.

The ROP conveyor system is modeled in a compartmentalized way, dividing it into cells of unit capacity arranged one after the other. The bins go through the cells with a fixed transportation time. When a bin is on an input cell of a station, it is directed depending on if it needs to go on this station or not. Each picking stations is simulated as a set of two complementary resources: the order picker which process only one bin at a time and an associated buffering resource with a finite capacity.

As illustrated in Fig.1, when a bin enters a picking station, it is placed in a buffer. The bins are processed in the order of their arrival at the station and are prepared as soon as the order picker is available. Preemption is forbidden.

After the completion of a bin preparation, the order picker tries to evacuate the prepared bins on the conveyor. If the picking station's output cell is empty, the evacuation process is done immediately, otherwise, the bins are maintained in the picking station's buffer and the order picker proceeds with his/her activities. The prepared bins are sent to the conveyor according to the FIFO rule.

Whenever the picking station buffer is saturated, a bin which should access to this station will remain on the input cell. This flow congestion hinders the bin transportation, making it impossible for bins to go from an upstream to a downstream station. Consequently, bins will be accumulated on the conveyor (see Fig. 2).

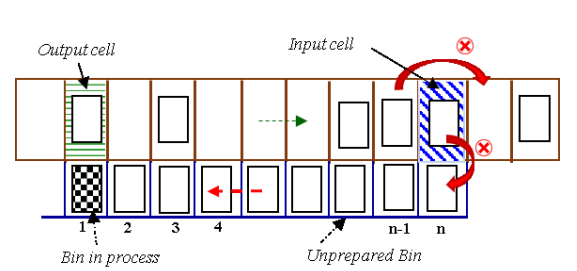

Fig. 3. A flow congestion situation

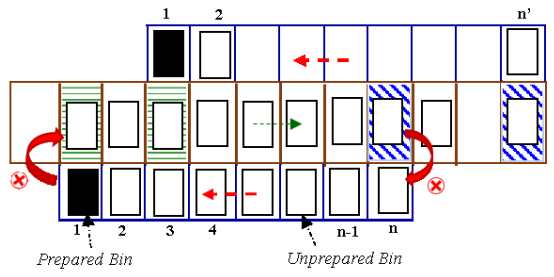

Fig. 2. A deadlock situation 
If the blocking situation persists and the station's output cell is upstream from its input cell, a deadlock can occur. A deadlock is a definitive blocking of the bins flow on the conveying segment connecting the input and the output cells of a saturated picking station (see Fig. 3). Thus, it requires a human intervention to unlock the flow.

To deal with the deadlock situations, two different business rules have been applied. The first rule aims to prevent the bins stationing in the output cell of the picking station. To do this, a bin is only allowed to access the output cell of a picking station if both the output cell and the one following it are empty. The second rule models the human intervention to handle deadlocks. To solve the deadlock problem, and ensure not falling back into a deadlock situation, only bins coming from the deadlocked station can arrive on the segment connecting the input and output cells. In this degraded mode, the conveyor is stopped right before the output cell and all stations which have their output cell in this segment are not allowed to free bins on the conveyor (see step 1 of Fig. 4). Then the last entered bin is placed on an additional buffer to enable the circulation of the bins (see step 2 of Fig. 4).

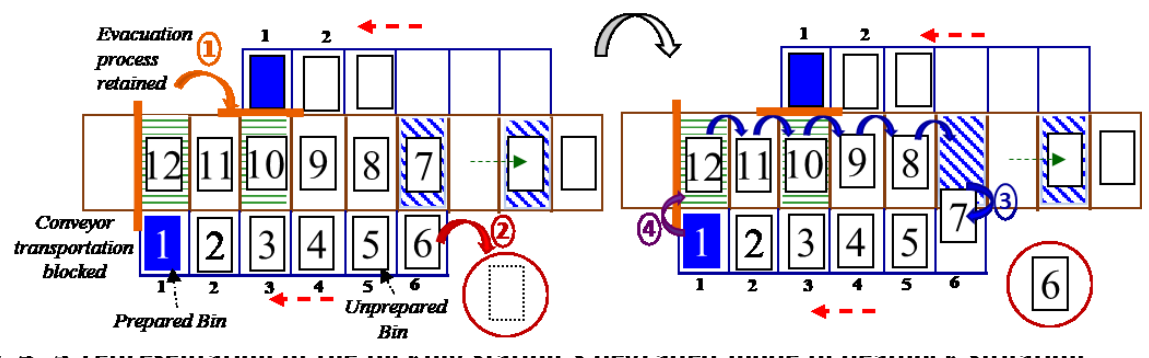

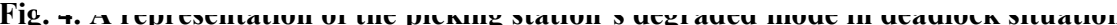

The bin holding at the station's input cell will then access the picking station's buffer and once the station's output cell is freed up, the order picker evacuates the prepared bin in the order of their preparations (see steps 3 and 4 on Fig. 4). The degraded mode stays on until the station becomes unsaturated. Then, the order picker puts back on the station's buffer the bin that was in the additional buffer and the flow retention is lifted.

To synthesize the key components of our simulation model, the bins are the entities flowing through the ROP system. The resources are: an order picker and a buffer for each picking station, the conveyor cells and an additional buffer of unit capacity for each station which is used only in a deadlock situations.

\section{Industrial Case Study}

The industrial case under study involves a company specialized in the manufacturing and marketing of products and tools for construction and decoration. Their activity volume is about 3500 orders per day.

We aim to study the impact of uncertainty and analyze the performance if the company's ROP system regarding a predictive scheduling. The system's configuration is composed of 4 stations: two pairs of parallel stations, for which the direction is opposite to the conveyor, as represented in Fig. 1. The buffer capacity of 
each picking station is of 10 bins. There are 50 bins to prepare, which visit on average $65 \%$ of the stations with minimum one station to visit and maximum 4 . The OP preparation times are centered around the company expected average time of $35 \mathrm{~s}$. We consider that preparation times uncertainty follows a truncated normal distribution with a mean of $30 \mathrm{~s}$ and a standard deviation (SD) of 10 .

In this case study, we draw attention to two different performance measurements: the makespan performance measure and the order pickers cumulative presence time (OPCPT) at their stations criterion which measures the order pickers unproductive times. The simulation model is executed for one simulation with 50 replications and the time unit is second.

First, we consider 3 types of predictive schedules obtained from different scheduling methods with the aim is to study the efficiency and the performance of these scheduling solutions while keeping the uncertainty level fixed. The first schedule represents the sequencing approach currently adopted by the company which is based on their know-how. The second schedule is a feasible solution generated by the solving of a deterministic linear model minimizing the OPCPT [15], stopped at a time limit of $3600 \mathrm{~s}$. The third schedule is obtained by considering the earliest due date sequencing rule for scheduling customer orders. Note that a schedule represents the bins sequencing and their launching times into the ROP system. In addition, the performance mean gap is the difference between the performance criterion value of the deterministic solution and the same performance criterion mean value of the solution with uncertainty.

Table 1. Difference in performance measurements of the three scheduling approaches under the same uncertainty level

\begin{tabular}{|c|c|c|c|c|c|c|}
\cline { 2 - 7 } \multicolumn{1}{c|}{} & \multicolumn{3}{c|}{ OPCPT for } & \multicolumn{3}{c|}{ Makespan for } \\
\hline Schedule & $\begin{array}{c}\text { Know-how- } \\
\text { based }\end{array}$ & $\begin{array}{c}\text { Linear } \\
\text { model } \\
\text { based }\end{array}$ & $\begin{array}{c}\text { Due date } \\
\text { based }\end{array}$ & $\begin{array}{c}\text { Know-how- } \\
\text { based }\end{array}$ & $\begin{array}{c}\text { Linear } \\
\text { model } \\
\text { based }\end{array}$ & $\begin{array}{c}\text { Due date } \\
\text { based }\end{array}$ \\
\hline $\begin{array}{c}\text { Without } \\
\text { uncertainty }\end{array}$ & 9609 & 8241 & 11865 & 8733 & 8896 & 9701 \\
\hline $\begin{array}{c}\text { Simulation } \\
\text { Mean value }\end{array}$ & 10802 & 9004 & 13573 & 9231 & 9788 & 10751 \\
\hline $\begin{array}{c}\text { Performance } \\
\text { Mean Gap in \% }\end{array}$ & 12.42 & 9.26 & 14.40 & 5.70 & 10.03 & 10.82 \\
\hline $\begin{array}{c}\text { Gap Confidence } \\
\text { interval in \% }\end{array}$ & {$[10.94 ; 13.88]$} & {$[7.77 ; 10.73]$} & {$[12.81 ; 15.97]$} & {$[4.30 ; 7.09]$} & {$[8.64 ; 11.40][9.26 ; 12.40]$} \\
\hline
\end{tabular}

Table 1. shows that the linear model-based schedule provides the best performance gap for the OPCPT criterion. The know-how-based schedule has not only the best performance gap for the makespan criterion but also the lowest mean value of makespan comparing to the other schedules. The due date-based schedule is the most unfordable schedule with the bigger performance gap for both makespan and OPCPT performance measurements. This could be explained by the fact that the due datebased scheduling method does not take into account the ROP system workload and only considers an external factor (customers due dates). The simulation model could be a decision tool for the company decision-makers, enabling them to choose the most adequate schedule to apply in the ROP system depending on their interests. 
The next experiment focuses on the impact of the variability of the uncertainty level. We considered the know-how-based schedule for which we consider different uncertainty levels by modifying the value of SD.

Table 2. Impact of the variability of the uncertainty parameter

\begin{tabular}{|c|c|c|c|c|c|c|}
\cline { 2 - 7 } & $\begin{array}{c}\text { OPCPT } \\
\text { Performance } \\
\text { Mean Gap in } \\
\%\end{array}$ & $\begin{array}{c}\text { OPCPT } \\
\text { Confidence } \\
\text { Interval in \% }\end{array}$ & $\begin{array}{c}\text { Makespan } \\
\text { Performance } \\
\text { Mean Gap in } \\
\%\end{array}$ & $\begin{array}{c}\text { Makespan } \\
\text { Confidence } \\
\text { Interval in \% }\end{array}$ & $\begin{array}{c}\text { Nb of } \\
\text { Deadlocks }\end{array}$ & $\begin{array}{c}\text { Nb of } \\
\text { deadlocks } \\
\text { Confidence } \\
\text { interval }\end{array}$ \\
\hline $\mathbf{S D}=\mathbf{5}$ & 7.83 & {$[6.61 ; 9.03]$} & 5.11 & {$[3.97 ; 6.24]$} & 2 & {$[1 ; 3]$} \\
\hline $\mathbf{S D = 1 0}$ & 12.42 & {$[10.94 ; 13.88]$} & 5.70 & {$[4.30 ; 7.09]$} & 3 & {$[2 ; 4]$} \\
\hline $\mathbf{S D}=\mathbf{1 5}$ & 13.21 & {$[11.60 ; 14.80]$} & 6.52 & {$[5.03 ; 7.99]$} & 5 & {$[3 ; 7]$} \\
\hline $\mathbf{S D}=\mathbf{2 0}$ & 16.28 & {$[14.41 ; 18.13]$} & 7.71 & {$[6.03 ; 9.37]$} & 9 & {$[7 ; 11]$} \\
\hline
\end{tabular}

The experiment shows the linear variation of the makespan performance mean gap with the increase of the level of uncertainty unlike the OPCPT performance mean gap. The reason behind the increasing gaps is that system started to generate blockages. In addition, due to the non-linearity of the number of deadlocks, the number of human interventions would be difficult to predict with increasing of the uncertainty level.

\section{Conclusion and Perspectives}

This paper develops a simulation model of a zone OP system with the aim to evaluate a predictive picking schedule under uncertainty. The work points out the impact of the variability of the preparation times on the system's performance measurements. By referring to the simulation, industrial decision-makers can anticipate on future deadlocks. They can also compare different scheduling methods and analyze the schedules resilience to uncertainty in order to find the best one that meets their needs. Further proposed analysis could be by considering other sources of uncertainty like the conveyor's system state (failure of a cell causing the conveyor to stop fractionally or entirely) which will add an extra layer of perturbation. Another complementary work is the coupling and interaction between simulation-based and optimization methods. We think this could be the key to absorb real scheduling uncertainties especially when the problem gets more complex.

\section{References}

1. Wäscher, G.: Order Picking: A Survey of Planning Problems and Methods. In: Dyckhoff, H., Lackes, R., and Reese, J. (eds.) Supply Chain Management and Reverse Logistics. pp. 323-347. Springer Berlin Heidelberg, Berlin, Heidelberg (2004). https://doi.org/10.1007/978-3-540-24815-6 15.

2. Guthrie, C., Fosso-Wamba, S., Arnaud, J.B.: Online consumer resilience during a pandemic: An exploratory study of e-commerce behavior before, during and after a 
COVID-19 lockdown. Journal of Retailing and Consumer Services. 61, 102570 (2021). https://doi.org/10.1016/j.jretconser.2021.102570.

3. Souiden, S., Cerqueus, A., Delorme, X., Rascle, J.-L.: Retail order picking scheduling with missing operations and limited buffer. IFAC-PapersOnLine. 53, 10767-10772 (2020). https://doi.org/10.1016/j.ifacol.2020.12.2859.

4. Zhang, J., Wang, X., Huang, K.: On-line scheduling of order picking and delivery with multiple zones and limited vehicle capacity. Omega. 79, 104-115 (2018). https://doi.org/10.1016/j.omega.2017.08.004.

5. Floudas, C.A., Lin, X.: Continuous-time versus discrete-time approaches for scheduling of chemical processes: a review. Computers \& Chemical Engineering. 28, 2109-2129 (2004). https://doi.org/10.1016/j.compchemeng.2004.05.002.

6. Sahinidis, N.V.: Optimization under uncertainty: state-of-the-art and opportunities. $\begin{array}{lllll}\text { Computers \& Chemical Engineering. 28, 971-983 (2004). } & \end{array}$ https://doi.org/10.1016/j.compchemeng.2003.09.017.

7. González-Neira, E.M., Montoya-Torres, J.R., Barrera, D.: Flow-shop scheduling problem under uncertainties: Review and trends. International Journal of Industrial Engineering Computations. 399-426 (2017). https://doi.org/10.5267/j.ijiec.2017.2.001.

8. Negahban, A., Smith, J.S.: Simulation for manufacturing system design and operation: Literature review and analysis. Journal of Manufacturing Systems. 33, 241-261 (2014). https://doi.org/10.1016/j.jmsy.2013.12.007.

9. Jeong, K.-C., Kim, Y.-D.: A real-time scheduling mechanism for a flexible manufacturing system: Using simulation and dispatching rules. International Journal of Production Research. 36, 2609-2626 (1998). https://doi.org/10.1080/002075498192733.

10. Tavakkoli-Moghaddam, R., Daneshmand-Mehr, M.: A computer simulation model for job shop scheduling problems minimizing makespan. Computers \& Industrial Engineering. 48, 811-823 (2005). https://doi.org/10.1016/j.cie.2004.12.010.

11. Framinan, J.M., Perez-Gonzalez, P., Escudero, V.F.-V.: The value of real-time data in stochastic flowshop scheduling: A simulation study for makespan. In: 2017 Winter Simulation Conference (WSC). pp. 3299-3310. IEEE, Las Vegas, NV (2017). https://doi.org/10.1109/WSC.2017.8248047.

12. de Koster, R.: Performance approximation of pick-to-belt orderpicking systems. European Journal of Operational Research. 72, 558-573 (1994). https://doi.org/10.1016/0377-2217(94)90423-5.

13. Klodawski, M., Jachimowski, R., Jacyna-Golda, I., Izdebski, M.: Simulation Analysis of Order Picking Efficiency with Congestion Situations. International Journal of Simulation Modelling. 17, 431-443 (2018). https://doi.org/10.2507/IJSIMM17(3)438.

14. Hong, S.: A performance evaluation of bucket brigade order picking systems: Analytical and simulation approaches. Computers \& Industrial Engineering. 135, 120-131 (2019). https://doi.org/10.1016/j.cie.2019.05.037. 